\title{
Cyclosporine A Inhibits TNF Production Without Decreasing TNF mRNA Levels
}

\author{
Daniel G. Remick, Dung T. Nguyen, Mark K. Eskandari, \\ Robert M. Strieter* and Steven L. Kunkel \\ Departments of Pathology and *Internal Medicine, \\ Box 0602 Room M5214 \\ 1301 Catherine Road \\ The University of Michigan Medical School, \\ Ann Arbor, Michigan 48109
}

Received May 1, 1989

\begin{abstract}
The role of cytokines in health and disease has received increasing attention and numerous investigations have explored the regulation of cytokine gene expression. Tumor necrosis factor$\alpha$ (TNF) has received particular attention because of its central role in septic shock and more recent work has shown its participation in transplant immunology. We explored the mechanism of cyclosporine A (CsA) modulation of complete Freunds adjuvant macrophage (CFA-MO) TNF gene expression. From 0.001 to $1 \mathrm{ug} / \mathrm{ml}$, CsA dose-dependently inhibited lipopolysaccharide (LPS) induced secreted bioactivity; at doses above $10 \mu \mathrm{g} / \mathrm{ml} \mathrm{CSA}$ was directly toxic to CFA-MO. However, there was no suppression of TNF mRNA levels, and CsA also did not inhibit the accumulation of cell-associated TNF. Thus, CsA modulates TNF gene expression in a previously undescribed manner. $\odot 1989$ Academic Press, Inc.
\end{abstract}

TNF is a potent cytokine with diverse pathologic and physiologic effects. In vitro, this polypeptide mediator modulates a wide range of activities in multiple cell types (1). Although its original description was that of cytolytic activity against murine solid tumors (2), further investigations have shown TNF to play a major role in the pathophysiology of several disease states. TNF has been extensively studied in recent years because of the central role of this mediator in septic shock (3), its participation in the pathophysiology of AIDS (4) and its role in transplant immunology, including both graft-versus-host disease (5) and allograft rejection (6). Elevated plasma levels of TNF have been detected in several clinical conditions including patients with septic shock (7), patients with parasitic infections (8), and patients actively rejecting renal allografts (6). The latter clinical study is of particular interest, as none of the patients in this transplantation study were receiving CsA. In animal studies, TNF has been shown to be an active mediator in the pathogenesis of murine cerebral malaria (9), and CsA demonstrated a protective effect in this experimental model (10). Additionally, CsA has been shown to inhibit TNF production by human peripheral blood monocytes (11). Data presented in

Abbreviations: CFA-MO, complete Freund's adjuvant elicited peritoneal macrophages; CM, complete media; CsA, cyclosporin A; LPS, lipopolysaccharide; TNF, tumor necrosis factor. 
the following studies demonstrate that CsA can decrease the production of extracellular TNF bioactivity without decreasing TNF mRNA, or the accumulation of intracellular TNF bioactivity.

\section{Materials and Methods}

Preparation of cells: Macrophages were elicited in CBA/J mice (Jackson Labs, Bar Harbor ME) by the intraperitoneal injection of CFA mixed 1:1 with normal saline. Two weeks later the cells were harvested and resuspended in complete media ([CM] RPMI 1640 with $2 \mathrm{mM}$ L-glutamine, $25 \mathrm{mM}$ HEPES and 1\% penicillin-streptomycin [Whittaker Bioproducts, Walkersville MD]). The cells were adhered for 1 hour in $35 \mathrm{~mm}$ or $100 \mathrm{~mm}$ tissue culture plates (Costar, Cambridge MA), pretreated for 30 minutes with the indicated doses of CsA (Sandoz) and then challenged with the indicated doses of LPS (E. coli 0111:B4, Sigma Chemical Co. St. Louis, MO).

Tumor nectosis assay: TNF bioactivity was measured in the WEHI 164 subclone 13 bioassay, as previously described (12). Briefly, samples were serially diluted in 96 well flat bottom plates in CM plus $1 \%$ fetal calf serum (FCS). WEHI cells were resuspended in CM with $10 \%$ FCS, 0.5 $\mathrm{ug} / \mathrm{ml}$ actinomycin D (Calbiochem, La Jolla CA), added to the cells and the plates incubated overnight at $370 \mathrm{C}$ in $5 \% \mathrm{CO}_{2} / 95 \%$ air. Twenty ul of MTT-tertazolium (Sigma) were added to each well, the plates incubated an additional 4 hours and the crystals dissolved with $0.04 \mathrm{~N} \mathrm{HCl}$ in isopropanol.

Viability: The viability of the adherent CFA-M0 was established by removing the supernatant media and adding back an additional $1 \mathrm{ml}$ of CM with $50 \mathrm{ul}$ of MTT-tetrazolium and allowing the plates to incubate 4 hours. The crystals were dissolved as above, and read spectrophotometrically at $550 \mathrm{~nm}$. The cells which received neither LPS nor CsA was assigned a viability of $100 \%$.

Northern blot analysis: RNA was isolated from the CFA-M0 three hours after LPS since this is the time of peak TNF specific mRNA. RNA was isolated by a modification of the method of Chirgwin et al (13) and Jonas et al (14) as previously described (15). The cells were overlaid with a solution of $25 \mathrm{mM}$ Tris- $\mathrm{HCl}, \mathrm{pH} 8.0,4.2 \mathrm{M}$ guanidine isothiocyanate, $0.1 \mathrm{M} 2$ mercaptoethanol and 0.5\% Sarkosyl. Cells were scraped, pipetted into a RNAse free tube and an equal volume of $100 \mathrm{mM}$ Tris- $\mathrm{HCl}, \mathrm{pH} 8.0,10 \mathrm{mM}$ EDTA and 1\% SDS added. The RNA was then extracted with chloroform-phenol, chloroform-isoamyl alcohol and alcohol precipitated. This RNA was then electrophoresed in formaldehyde $1 \%$ agarose gels, transblotted to nitrocellulose, baked and prehybridized. The blots were then hybridized with a 32P end labeled probe specific for TNF, 5'-GGT-CAC-CCT-TCT-CCA-GCT-GGA-AGA-C-3' (16). The blot was then stripped and reprobed for B-actin mRNA using 5'-GGC-TGG-GGT-GTT-GAA-GGTCTC-AAA-CAT-GAT-CTG-GGT-CAT-CTT-3' (17). (Probes were the generous gifts of Dr. Glen Andrews and Henry Showell, Pfizer Pharmaceutical Co. Groton CT).

\section{Results}

Our first studies examined the ability of CsA to inhibit cell viability at doses from 0.001 to $100 \mathrm{ug} / \mathrm{ml}$. Figure 1 shows that CSA did not decrease cell viability below a concentration of 1 $\mu \mathrm{g} / \mathrm{ml}$, while, at $10 \mathrm{ug} / \mathrm{ml}$ and above, CsA was directly toxic to the cells. In our next studies, we evaluated the ability of CsA to dose dependently suppress lipopolysaccharide (LPS) induced TNF production. As shown in Figure 2, CsA dose dependently suppressed TNF production in response to either $100 \mathrm{ng} / \mathrm{ml}$ or $10 \mathrm{ug} / \mathrm{ml}$ of LPS. This TNF production was assessed at 6 hours post LPS challenge since this represented the peak of bioactivity in macrophage supernatants (15).

In contrast to the reduction in the secretion of TNF biological activity, CsA had no effect on the levels of TNF mRNA (Figure 3). The addition of CsA $(.001$ to $1 \mathrm{ug} / \mathrm{ml})$ did not alter the accumulation of TNF mRNA, while the supernatants of these same cultures again showed a dose dependent decrease in the secreted bioactivity. These studies demonstrated that CsA inhibited the production of supernatant bioactivity without decreasing mRNA. To further evaluate the 


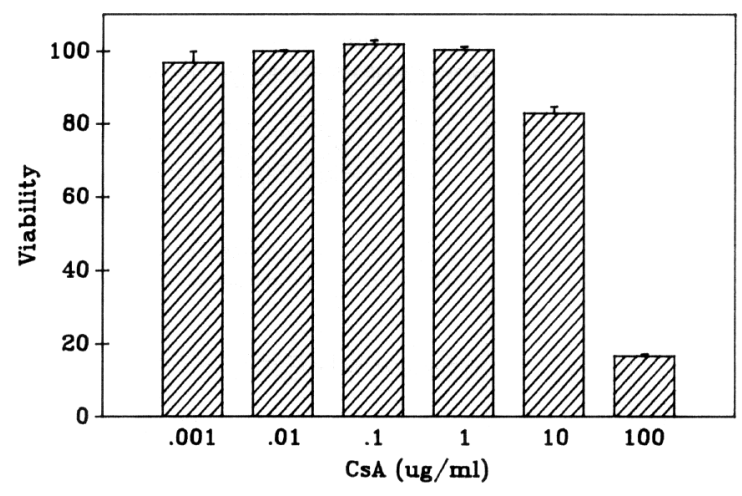

Figure 1. CsA toxicity to CFA-MO. CsA was added at the indicated doses and 30 minutes later all cultures were challenged with $10 \mathrm{ug} / \mathrm{ml}$ LPS. The viability was determined 6 hours after the LPS. CsA at 10 and $100 \mathrm{ug} / \mathrm{ml}$ markedly decreased cell viability. Each point is the mean \pm SEM of triplicate measurements.

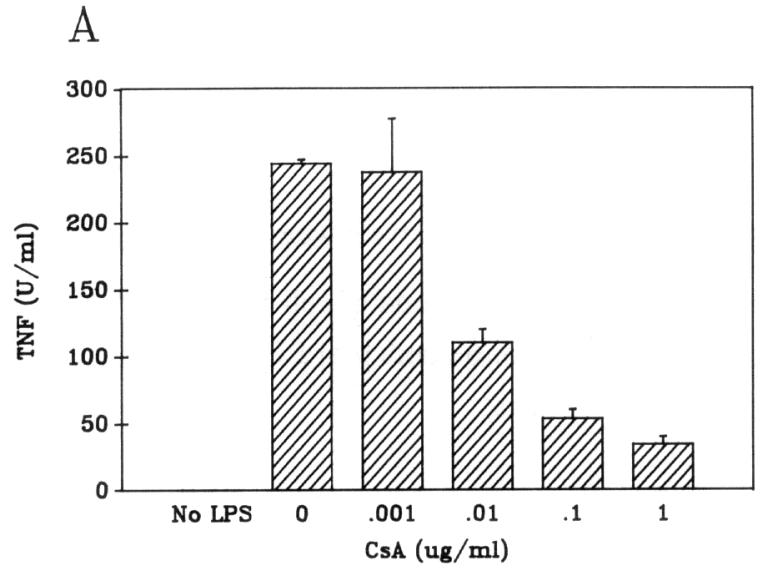

\section{B}

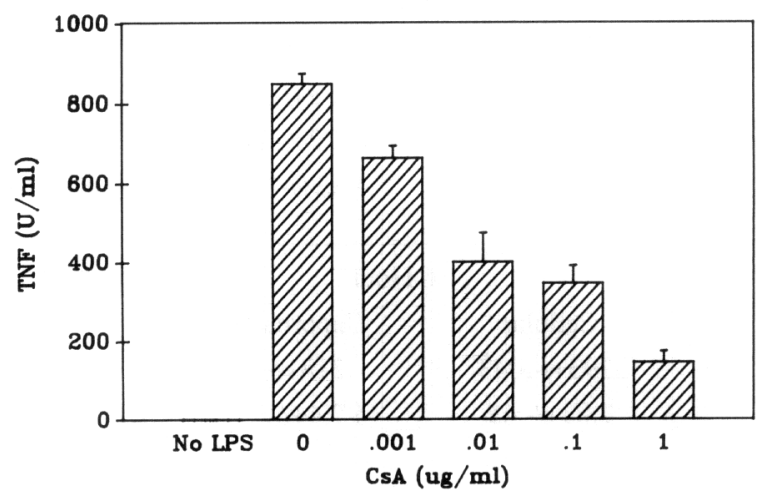

Figure 2. Dose-dependent CsA inhibition of TNF supernatant bioactivity. CsA dose dependently suppressed TNF secreted bioactivity when the cells are challenged with either $100 \mathrm{ng} / \mathrm{ml}$ (A) or $10 \mathrm{ug} / \mathrm{ml}$ (B) LPS. The supernatants were collected 6 hours after LPS challenge. Each value is the mean \pm SEM for triplicate measurements. 


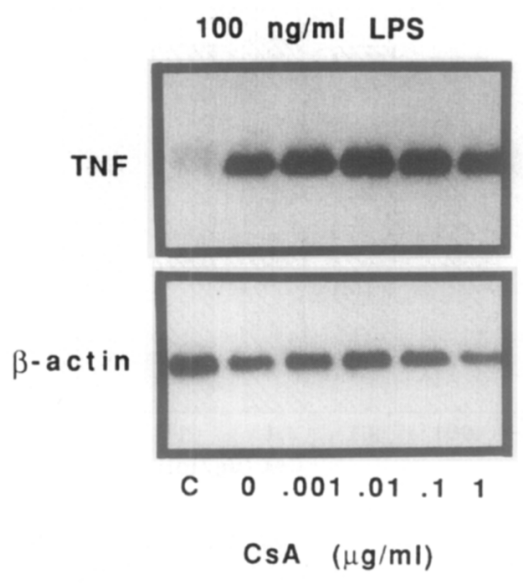

Figure 3. Northern blot of failure of CsA to inhibit TNF mRNA. Cells were treated as in Figure 2, except the RNA was isolated after 3 hours, at the peak of TNF mRNA accumulation. The cells were challenged with $100 \mathrm{ng} / \mathrm{ml}$ of LPS. CsA failed to inhibit TNF mRNA accumulation at any dose, but there was no effect on B-actin accumulation. The upper panel is the blot probed for TNF, the lower panel is the blot stripped and then reprobed for B-actin. $C$ is control, cells which did not receive CsA or L.PS.

level of TNF regulation, cell-associated TNF levels were measured, to assess whether there was failure of translation or blockade in the secretion of cell-associated TNF. Table 1 provides data that the cell-associated levels, either 3 or 6 hours post LPS, are not decreased by CsA treatment, but supernatant bioactivity is suppressed.

Table 1: CsA Inhibition of Supernatant but Not Cell-Associated TNF

\begin{tabular}{cccc} 
& \multicolumn{2}{c}{3 Hour } \\
Control & $.037+/-.005$ & $.153+/-.006$ & $.233+/-.071$ \\
LPS & $5.28+/-.87$ & $39.72+/-11.35$ & $52.78+/-12.14$ \\
LPS/CSA & $4.62+/-1.3$ & $4.43+/-.275^{*}$ & $8.77+/-1.27^{*}$ \\
& & & \\
& & & \\
& Cellular & Sour & Total \\
Control & $.193+/-.043$ & $.218+/-.07$ & $.427+/-.12$ \\
LPS & $7.03+/-.65$ & $97.4+/-3.15$ & $102.27+/-2.86$ \\
LPS/CsA & $5.47+/-.32$ & $8.12+/-2.76^{*}$ & $15.76+/-2.61^{*}$ \\
\hline
\end{tabular}

The CFA-M0 cells were pretreated with $1 \mathrm{ug} / \mathrm{ml}$ CsA for 30 minutes, then stimulated with LPS. At the indicated time the cells were scraped, resuspended in $2 \mathrm{ml}$ of $\mathrm{CM}$ and frozen and thawed 3 times. Each value is the mean $+/-S E M$ of the TNF units $/ \mathrm{ml}$ for 3 determinations.

$*=p<0.05$ compared to LPS by Students t-test. 


\section{Discussion}

Collectively, these data demonstrate that CsA is effective in inhibiting TNF production without depressing cell-associated TNF levels or decreasing TNF mRNA. Therefore, this inhibition by CsA represents a different mechanism than that observed with either dexamethasone (18) or prostaglandin $\mathrm{E}_{2}\left(\mathrm{PGE}_{2}\right)$ (15). Specifically, CsA can suppress TNF production without decreasing TNF mRNA, while either dexamethasone or PGE 2 block TNF transcription. These studies show that the regulation of TNF gene expression by CsA is complex, and it is possible that there is a partial blockade of both translation and secretion of TNF. Alternatively, the intracellular levels may be under different regulatory mechanisms, such that at a certain intracellular level TNF inhibits its own translation, and CsA only blocks at the level of secretion. Additionally, a mechanism of regulation is defined that differs from that observed for interleukin 2, where CsA has been demonstrated to suppress lymphocyte production of IL-2 at the level of mRNA (19). This differential regulation may have implications in transplant therapy, since it would be possible for a patient to have a pool of TNF mRNA available for rapid translation, even with theraputic levels of CSA.

\section{Acknowledgments}

This work is supported by NIH grants HL31237, HL31963, HL35276, and HL39339. Dr. Kunkel is an Established Investigator of the American Heart Association. The authors wish to thank Cassandra Narvab for excellent secretarial assistance.

\section{References}

1. Le, J. \& Vilcek, J. Lab. Invest. (1987) 56, 234-248.

2. Carswell, E.A., Old, L.J., Kassel, R.L., Green, S.,Fiore, N. \& Williamson, B. Proc. Natl. Acad. Sci. U.S.A. (1975) 72, 3666-3670.

3. Beutler, B. \& Cerami, A. Annu. Rev. Biochem. (1988) 57, 505-518.

4. Lahdevirta, J., Maury, C.P., Teppo, A.M. \& Repo, H. Am. J. Med. (1988) 85,289-291.

5. Piguet, P.F., Grau, G.E., Allet, B. \& Vassalli, P. J. Exp. Med. (1987) 166, 1280-1285.

6. Maury, C.P. \& Teppo, A.M. J. Exp. Med. (1987) 166, 1132-1137.

7. Waage, A., Halstensen, A. \& Espevik, T. Lancet (1987) 1, 355-357.

8. Scuderi, P., Sterling, K.E., Lam, K.S., et al. Lancet (1986) 2, 1364-1365.

9. Grau, G.E., Fajardo, L.F., Piguet, P.F., Allet, B., Lambert, P.H. \& Vassaili, P. Science (1987) 237,1210-1212.

10. Grau, G.E., Gretener, D. \& Lambert, P.H. Immunology. (1987) 61,521-525.

11. Espevik, T., Figari, I.S., Shalaby, M.R., et al. J. Exp. Med. (1987) 166,571-576.

12. Espevik, T., \& Nissen-Meyer, J. J. Immunol. Meth. (1986) 95, 99-105.

13. Chirgwin, J.M., Przybyca, A.E., MacDonald, R.J., \& Rutter, W.J. (1987) Biochem. 18,5294-5299.

14. Jonas, E., Sargent T.D., \& Davis, I.B. (1985) Proc. Natl. Acad. Sci. USA 82,5413-5416.

15. Kunkel, S.L., Spengler, M., May, M.A., Spengler, R., Larrick, J. \& Remick, D. J. Biol. Chem. (1988) 263,5380-5384.

16. Pennica, D., Nedwin, G.F., \& Hayflick, J.S. (1984) Nature 312,724-729.

17. Tokunaga, K., Traniguchi, H., Hoda, K., Shimizu, M., \& Sakiyama, S. (1986) Nuc. Acid Res. 14,2829.

18. Beutler, B., Krochin, N., Milsark, I.W., Luedke, C. \& Cerami, A. Science (1986) 232, 977-980.

19. Elliott, J.F., Lin, Y., Mizel, S.B., Bleackley, R.C., Harnish, D.G. \& Paetkau, V. Science (1984) 226,1439-1441. 